\title{
Warunki skutecznej realizacji programów populacyjnych badań przesiewowych w kierunku nowotworów
}

\author{
Elsebeth Lynge ${ }^{1}$, Sven Törnberg ${ }^{2}$, Lawrence von Karsa ${ }^{3}$, Nereo Segnan ${ }^{4}$, \\ Johannes J.M. van Delden ${ }^{5}$
}

\author{
Determinants of successful implementation of population-based \\ cancer screening programmes
}

\begin{abstract}
Komentarz
Prezentujemy Państwu tłumaczenie artykułu poświęconego organizacji skriningów populacyjnych. Grupa ekspertów uznanych w dziedzinie badań skriningowych zebrała i w syntetycznej formie przedstawiła najważniejsze warunki, których spełnienie jest konieczne, aby można było mówić o dobrze funkcjonującym skriningu. Artykuł wydaje nam się na tyle cenny, że postanowiłyśmy przybliżyć go osobom, które są lub będą włączone w organizację i realizację skriningu w Polsce. Stanowi on rozwinięcie artykułu zatytułowanego Zalecenia komitetu ekspertów działającego w ramach projektu EuSANH dla Ministra Zdrowia w sprawie organizacji skriningów populacyjnych, opublikowanego w "Nowotwory Journal of Oncology" 2014, 64, 5.
\end{abstract}

W celu ułatwienia realizacji populacyjnych programów badań przesiewowych w kierunku nowotworów podsumowano dotychczas zdobyte w Europie doświadczenia w tym zakresie. Wymieniono w punktach najważniejsze kwestie, które obywatele, grupy rzeczników, politycy, osoby organizujące opiekę zdrowotną oraz pracownicy służby zdrowia powinni rozważyć podczas planowania, realizacji i prowadzenia badań przesiewowych w kierunku raka. Lista jest na tyle ogólna, że ma zastosowanie zarówno do skriningu raka piersi, jak i szyjki macicy oraz jelita grubego. Lista powstała

${ }^{1}$ Department of Public Health, University of Copenhagen, Denmark

${ }^{2}$ Department of Cancer Screening, Karolinska University Hospital, Stockholm, Sweden

${ }^{3}$ International Agency for Research on Cancer, Lyon, France

${ }^{4}$ Department of Cancer Screening and Unit of Cancer Epidemiology, CPO Piemonte and S. Giovanni University Hospital, Torino, Italy

${ }^{5}$ Julius Center for Health Sciences and Primary Care, Medical Humanities, University Medical Center, Utrecht, The Netherlands

Tłumaczenie: Anna Dębskaa , Dorota Cianciarab ${ }^{b}$ Maria Piotrowicz ${ }^{a}$, Joanna Bogusz ${ }^{a}$, Katarzyna Kwiatkowskaa , Magdalena Bielska-Lasota ${ }^{a}$

Tłumaczenie pracy zamieszczonej w Eur J Cancer 2012; 48: 743-748

(za zgodą autorów i wydawcy Elsevier)

aNarodowy Instytut Zdrowia Publicznego — Państwowy Zakład Higieny

bZakład Epidemiologii i Promocji Zdrowia, Szkoła Zdrowia Publicznego, Centrum Medyczne Kształcenia Podyplomowego 
na podstawie dowodów przedstawionych w trzech publikacjach Unii Europejskiej, zawierających wytyczne w sprawie kontroli jakości badań przesiewowych i diagnostyki raka. Dodatkowo została wzbogacona piśmiennictwem oraz doświadczeniami ekspertów prezentowanymi w czasie warsztatu w ramach European Science Advisory Network. Realizacja programu badań przesiewowych w kierunku raka powinna być podzielona na siedem etapów: 1) przygotowanie do planowania, 2) kompleksowe planowanie, 3) badanie wykonalności, 4) pilotaż i wdrożenie procesu, 5) rozwój serwisu usług skriningowych, 6) uruchomienie programu badań przesiewowych na dużą skalę oraz 7) zapewnienie trwałości. O realizacji każdego etapu można mówić jedynie wtedy, gdy zostanie spełniona określona liczba warunków. Pomyślna realizacja programu badań przesiewowych wymaga akceptacji społecznej oraz użycia najlepszych praktyk opartych na dowodach i weryfikacji adekwatności wykonania na każdym etapie realizacji.

NOWOTWORY Journal of Oncology 2014; 64, 6: 511-517

Słowa kluczowe: rak, badania przesiewowe, skriningi, programy populacyjne

\section{Wprowadzenie}

Badania przesiewowe i wczesne wykrywanie bezobjawowych przypadków stanowią istotne działania w zwalczaniu raka piersi, szyjki macicy i jelita grubego. Zgodnie z zaleceniem Rady Unii Europejskiej (UE) z 2003 r. [1] wiele krajów europejskich wdrożyło programy badań przesiewowych dla wybranych lub wszystkich trzech wyżej wymienionych nowotworów. Dodatkowe programy są obecnie planowane lub wdrażane.

Zgodnie z zasadami dobry test przesiewowy powinien być prosty i łatwy w użyciu, jednak pełny potencjał prewencyjny testu przesiewowego może być realizowany tylko w ramach programu badań przesiewowych, który jest złożonym procesem organizacyjnym. Aby ułatwić przyszłą realizację programów populacyjnych badań przesiewowych w krajach europejskich, cenne jest podsumowanie doświadczeń zdobytych w ramach funkcjonujących obecnie programów w całej Europie. Mając to na uwadze, w Sztokholmie w dniach 7-9 lutego 2011 roku zebrała się, działająca w ramach European Science Advisory Network for Health, grupa ekspertów. Niniejszy artykuł jest sprawozdaniem z wyników tych prac.

Celem badań przesiewowych w kierunku nowotworów jest zmniejszenie umieralności na choroby, którym dany skrining jest poświęcony. Jeśli zmiany przedrakowe są wykrywane i leczone, częstość występowania choroby powinna również zmniejszyć się. Aby skrining mógł osiągnąć swój cel, musi być spełnionych wiele warunków. Raport ten przedstawia kluczowe punkty, które wszyscy obywatele, grupy rzeczników, politycy, osoby organizujące opiekę zdrowotną oraz pracownicy służby zdrowia powinni rozważyć przy planowaniu, wdrażaniu i realizacji programów populacyjnych badań przesiewowych w kierunku raka. Poniższa lista warunków powstała w oparciu o dowody z piśmiennictwa naukowego i doświadczenia ekspertów. Główna część dowodów jest przedstawiona w wytycznych UE w sprawie zapewnienia jakości badań przesiewowych i diagnozy [2-4].

Lista obejmuje etapy, które występują podczas realizacji programu: od społecznej debaty na temat nowych środ- ków zwalczania raka do zapewnienia stabilności dobrze realizowanego programu badań przesiewowych. Udane wdrożenie badań przesiewowych obejmuje wiele czynności. Są one pogrupowane następująco: przygotowanie do planowania, kompleksowe planowanie, badanie, wykonalność, pilotaż, poszerzanie zasięgu działania skriningu i zapewnienie trwałości. Punkty są ogólne i mają zastosowanie do skriningu raka piersi, szyjki macicy i jelita grubego. W kilku przypadkach kluczowe punkty zostały powtórzone, jeśli mają znaczenie dla więcej niż jednego etapu.

\section{Uwarunkowania \\ Przygotowanie do planowania}

Podjęcie decyzji o wprowadzeniu skriningów musi zawsze poprzedzać upowszechnienie zrozumienia celu oraz korzyści i zagrożeń związanych z jego działaniem, zarówno wśród profesjonalistów, jak i społeczeństwa. Taki wymóg wiąże się z koniecznością organizacji konsultacji społecznych. Następny krok to przegląd istniejących dowodów i rekomendacji w świetle uwarunkowań lokalnych.

Kluczowe działania na tym etapie to:

- przegląd literatury naukowej;

- zgromadzenie danych epidemiologicznych na temat występowania choroby, stopnia zaawansowania oraz przeżyć;

- zgromadzenie informacji na temat dostępności i jakości leczenia;

- zrozumienie roli badań przesiewowych w zwalczaniu raka;

- ocena efektów zwalczania raka po wdrożeniu skriningów;

- analiza doświadczeń w tym zakresie z innych krajów;

- rozpowszechnianie wiedzy wśród profesjonalistów i społeczeństwa na temat korzyści i zagrożeń związanych z badaniami przesiewowymi;

- wola polityczna, zaangażowanie na wszystkich istotnych poziomach (UE, państw członkowskich i regionów);

- decyzja o wzięciu politycznej odpowiedzialności za ten proces;

- przegląd istniejących wytycznych; 
- ocena dostępności leczenia oraz wyposażenia (zarówno pod względem kompetencji, jak i zasobów);

- ocena zaplecza/barier dla wdrażania zorganizowanych badań przesiewowych;

- ocena skutków ekonomicznych i opłacalności programu;

- formalna decyzja i przydział budżetu;

- organizacja ciągłej debaty społecznej o sposobie realizacji, efektach zdrowotnych i kosztowych skriningu, a także stałego wkładu do procesu (zasoby finansowe, ludzkie, materialne, czasowe itp.).

\section{Kompleksowe planowanie: wykonalność planu skriningowego, profesjonalne wykonanie, organizacja, finansowanie i zapewnienie jakości (QA - quality assurance)}

Jeśli została podjęta polityczna decyzja, aby rozpocząć proces tworzenia programu badań przesiewowych, kolejnym krokiem jest kompleksowe planowanie, które powinno obejmować cały multidyscyplinarny proces badań skriningowych oraz aspekty organizacyjne. Jednym z celów kompleksowego planowania jest uniknięcie niepotrzebnych opóźnień i kosztów w przyszłości.

Wykonalność planu badań przesiewowych powinna być sprawdzona przed szczegółowym planowaniem badań pilotażowych. Planowanie powinno obejmować: profesjonalne wykonanie, aspekty organizacyjne i finansowe, a także zakres i zawartość kompleksowego programu zapewnienia jakości. Początkowe plany powinny również wziąć pod uwagę ramy czasowe, w których różne kwestie będą dalej rozwijane.

Kluczowe punkty na tym etapie to:

- wspieranie „zaangażowanego rozumienia” procesu skriningu wśród profesjonalistów;

- planowanie infrastruktury;

- powołanie ośrodka koordynującego z uprawnieniami nadzorującymi;

- upewnienie się, że badania przesiewowe są postrzegane przez osoby zaangażowane jako proces;

- wyznaczenie dysponenta procesu, władnego uruchomić proces i nadzorować jego jakość;

- rozwój organizacyjny (samokształcenie, nastawienie na jakość, rozwiązywanie problemów, budowanie zaufania);

- ustanowienie oddzielnego budżetu na koordynację procesu;

- multidyscyplinarne zarządzanie przypadkami;

- współpraca między systemem wykonywania badań przesiewowych i systemem leczenia;

- odpowiednia ocena jakości diagnostyki;

- odpowiedni program informatyczny monitorujący badania przesiewowe z dostępem i możliwością łączenia rejestrów, np. populacyjnych, rejestrów pacjentów, rejestrów nowotworów;
— kompleksowy system informacyjny mogący służyć różnym celom;

- opracowanie planu zapewnienia jakości, w tym jakości technicznej (QA - quality assurance);

- przyjęcie zatwierdzonego planu QA;

- definicja parametrów pracy i dopuszczalnych poziomów, w tym norm wymaganych od pracowników służby zdrowia;

— umowy ze świadczeniodawcami;

- system audytu i szkoleń;

- narzędzia oceny do wykluczenia złych wykonawców;

- rozważanie systemu akredytacji lub innych kompleksowych systemów dla zapewnienia właściwego świadczenia usług.

\section{Przygotowanie wszystkich elementów procesu skriningowego, z włączeniem sprawdzenia wykonalności}

Opierając się na kompleksowym planowaniu, na tym etapie testuje się wykonalność świadczeń skriningowych i kluczowych elementów zarządzania programem. Testowanie winno się odbyć w ramach badań na małą skalę, z ograniczoną liczbą zasobów finansowych, technicznych, ludzkich i czasowych w celu uzyskania wstępnych wyników. Wyniki badania powinny być uwzględnione $w$ rewizji wstępnych planów, lub jeśli zachodzi taka potrzeba, przed rozpoczęciem badań pilotażowych na większą skalę.

Kluczowe punkty na tym etapie to:

- przegląd protokołu ze studium wykonalności ${ }^{1}$ pod kątem naukowym i etycznym;

- prawidłowe i zrównoważone informacje na temat "korzyści i ryzyka";

- opracowanie strategii komunikacji z zaangażowanymi podmiotami;

- zaangażowanie społeczeństwa;

- sprecyzowanie kwestii ochrony danych i zachowania poufności;

- utworzenie formalnego nadzoru programów badań przesiewowych;

- naukowe publikacje wyników studium wykonalności.

\section{Pilotowanie i modyfikacja (jeśli konieczna) wszystkich elementów procesu skriningu, w tym zapewnienia jakości}

W Anglii i wielu innych krajach europejskich realizacja programu badań przesiewowych w kierunku raka piersi, szyjki macicy i jelita grubego rozpoczęła się od pilotażu w określonych regionach. Na podstawie wyników tego do-

1Protokół wykonalności zawiera wyniki zebrane w czasie studium wykonalności. Celem realizacji Studium Wykonalności jest przede wszystkim zbadanie zasadności realizacji projektu w proponowanym kształcie. 
świadczenia programy zostały rozszerzone do skali krajowej [5]. W Finlandii realizacja programów rozpoczęła się od losowo wybranych kohort i była stopniowo rozszerzana na wszystkie docelowe grupy wieku [6]. Taka kolejność umożliwiła ocenę efektów programu na drodze badań randomizowanych [7]. Podejście fińskie wymaga, aby decyzja o podjęciu badań przesiewowych zapadła na szczeblu krajowym, a także aby dostępny był krajowy rejestr ludności. Takie podejście pozwala na opartą na dowodach modyfikację programu przed wprowadzeniem go w całym kraju.

Plan pilotażowego wdrażania rozpoczyna się od wyboru jednego lub kilku regionów pilotażowych. Na tym etapie nadzór i szkolenie są bardzo ważne z uwagi na jak najszybszą możliwość dostrzeżenia pojawiających się problemów. Etap pilotażowy służy również jako poligon doświadczalny dla ram prawnych. Efekty pilotażu powinny być przedstawione w literaturze naukowej i szeroko rozpropagowane wśród planistów zdrowia, polityków i pracowników służby zdrowia. Opierając się na pilotażu, powinny zostać określone finansowe wymagania związane $z$ rozwojem programu.

Kluczowe punkty na tym etapie to:

- ustalenie budżetu,

- ustalenie zobowiązań finansowych,

- nadzór i szkolenie pracowników programu skriningowego,

- testowanie ram prawnych,

- możliwość wykluczenia złych wykonawców,

- naukowe publikacje efektów pilotażu/ów.

\section{Od pilotażu do świadczeń skriningowych}

Ten etap jest w rzeczywistości wdrożeniem interwencji, którą był pilotaż. Wszystkie punkty z poprzedniego etapu muszą być odniesione do programu w pełni wdrożonego. Efektywna komunikacja dotycząca wniosków z dotychczasowych doświadczeń w procesie wdrażania powinna przyczynić się do rozwoju zaufania społecznego.

Kluczowe punkty na tym etapie to:

- wyłanianie i kontraktowanie lokalnych, regionalnych i krajowych zespołów programowych, określenie zakresu odpowiedzialności;

- ustanowienie infrastruktury dla koordynacji współpracy z placówkami ochrony zdrowia;

- identyfikacja ewentualnych przeszkód;

- opracowanie planu ewaluacji;

— dostępność personelu (kompetencje i liczby);

- multidyscyplinarne zarządzanie przypadkami;

- szkolenia specjalistyczne, centra referencyjne;

- kompleksowy system informacji, obejmujący wszystkie etapy procesu;

- współpraca między systemem badań przesiewowych, leczeniem i systemami informatycznymi;

- zapewnienie jakości w zakresie techniki (TQA - technical quality assurance);
- zmniejszanie barier dla uczestnictwa;

- narzędzia do wspierania „posłuszeństwa”;

- rzecznictwo i współpraca z lokalnymi organizacjami społeczeństwa obywatelskiego;

— zaufanie ludności do systemu.

\section{Uruchomienie programu badań przesiewowych na dużą skalę. Intensywne monitorowanie rozpoczynajq̨cego się programu i korygowanie problemów $\mathrm{z}$ jakościq}

Utrzymanie wysokiej jakości usług w zakresie badań przesiewowych wymaga ciągłego nadzoru i rygorystycznej sprawozdawczości naukowej. Uwagę należy zwrócić na wykonywanie działań podejmowanych na każdym etapie procesu badań przesiewowych, od informacji i zaproszenia do wzięcia udziału w badaniach przesiewowych zaczynając - poprzez ocenę materiału i diagnostykę — do leczenia zmian wykrytych w badaniach.

Kluczowe punkty na tym etapie to:

- nadzorowanie wszystkich etapów procesu;

- możliwość wykluczenia złych wykonawców;

- tworzenie możliwości do testowania nowych technologii;

- monitorowanie korzyści i szkód z badań przesiewowych;

- publikacje naukowe z efektów uzyskanych na tym etapie.

\section{Zapewnienie trwałości}

Zapewnienie zrównoważonego, trwałego funkcjonowania jest niezbędne do osiągnięcia efektu badań przesiewowych pod postacią zmniejszenia obciążenia chorobami nowotworowymi w populacji. Utrzymanie wysokiej jakości programów wymaga odpowiedniego, stałego wsparcia finansowego. W celu podtrzymania poparcia społecznego niezbędna jest odpowiednia komunikacja dotycząca informacji z przebiegu wykonania programu i jego efektów. Informowanie społeczeństwa wymaga długofalowej oceny efektów, prowadzonej za pomocą odpowiednio zaplanowanych badań, a także składania raportów o wykonaniu zadań oraz wdrożenia procedur follow-up dla skriningu.

Kluczowe punkty na tym etapie to:

- przekazywanie efektów badań przesiewowych w sposób dokładny i zrozumiały;

- budowanie zaufania wśród społeczeństwa;

- umocowanie organizacyjne;

- zapewnienie odpowiednich zasobów finansowych i zaangażowania politycznego.

\section{Dyskusja}

Od ponad 20 lat podkreślane jest znaczenie badań przesiewowych jako narzędzia zwalczania raka w UE. W Europejskim Kodeksie Walki z Rakiem od 1989 r. istnieją następujące zalecenia "kobiety powinny regularnie uczestniczyć w badaniach przesiewowych w kierunku raka 
Tabela I. Stan wdrażania badań skriningowych w 27 krajach członkowskich UE w 2007 roku (zaadaptowano z von Karsa i in. [12])

\begin{tabular}{|c|c|c|c|}
\hline $\begin{array}{l}\text { Europejskie rekomendacje* } \\
\text { Populacja docelowa UE }\end{array}$ & $\begin{array}{c}\text { Rak piersi } \\
\text { K, wiek 50-69 } \\
59 \mathrm{mln}\end{array}$ & $\begin{array}{c}\text { Rak szyjki macicy } \\
\text { K, wiek 30-60 } \\
109 \mathrm{mln}\end{array}$ & $\begin{array}{c}\text { Rak jelita grubego } \\
\text { M i K, wiek 50-74 } \\
136 \mathrm{mln}\end{array}$ \\
\hline \multicolumn{4}{|l|}{ Procentowy udział populacji docelowej } \\
\hline \multicolumn{4}{|l|}{ w skriningu: } \\
\hline — populacyjnym, całkowicie wdrożonym & $41 \%$ & $22 \%$ & $0 \%$ \\
\hline — populacyjnym, w trakcie wdrażania, pilotaż, planowanie & $50 \%$ & $29 \%$ & $43 \%$ \\
\hline — nieobejmujący całej populacji & $6 \%$ & $47 \%$ & $27 \%$ \\
\hline — z wyłączeniem określonych regionów i/lub grup wieku & $2 \%$ & $2 \%$ & $22 \%$ \\
\hline — brak jakiejkolwiek oferty programu & $2 \%$ & $<1 \%$ & $8 \%$ \\
\hline
\end{tabular}

*Grupy wieku rekomendowane do włączenia do badań przesiewowych w kierunku raka piersi i raka jelita grubego przez UE [1], dolna granica wieku osób do badań przesiewowych raka szyjki macicy zalecana przez Arbyna i in. [3]

szyjki macicy” oraz, jeśli to możliwe, „kobiety po 50 roku życia powinny uczestniczyć w badaniach przesiewowych w kierunku raka piersi" [8]. Wymagania dotyczące organizacji populacyjnych badań przesiewowych były podkreślane w pierwszych wytycznych dotyczących kontroli jakości diagnozy raka piersi [9] oraz raka szyjki macicy [10] z 1993 roku, a następnie rozwinięte w pracach przygotowujących zalecenia w sprawie badań przesiewowych Rady UE z 2003 roku [11]. Zgodnie z zaleceniami Rady, państwa członkowskie UE jednomyślnie przyjęły standardy realizacji programów przesiewowych w kierunku raka piersi, szyjki macicy i jelita grubego [1].

Jednak faktyczne wdrożenie realizacji programów populacyjnych badań przesiewowych w UE jest jeszcze dalekie od zakończenia. Do 2007 roku niezorganizowany skrining raka szyjki macicy był jedyną dostępną opcją dla prawie połowy docelowej populacji europejskiej, a 30\% (8\% bez dostępu do usług i 22\% nieobjętych usługami) kobiet i mężczyzn w populacji europejskiej badania przesiewowe raka jelita grubego w ogóle nie były oferowane [12] (tab. I). Objęcie programem badań przesiewowych w kierunku raka jelita grubego znacznie się poprawiło po roku 2007, na przykład we Włoszech do końca 2008 roku 36\% mężczyzn i kobiet w wieku od 50 do 69 lat zostało zaproszonych do badań przesiewowych, polegających na badaniu krwi utajonej w kale co dwa lata. Przebadano 1171000 osób — odsetek zgłoszeń 47,5\% [13]. W 2009 roku programy we Francji i Anglii stały się programami krajowymi.W 2013 roku rozpoczęło się upowszechnianie programów w Holandii, a w 2014 roku w Danii. Należy podkreślić, że działania skriningowe według opublikowanych zaleceń nie zostały jeszcze ujednolicone w całej UE. Na przykład do roku 2009 liczba rekomendowanych testów przesiewowych w kierunku raka szyjki macicy wykonanych w ciągu życia pacjentki waha się od 6 do 50+ w zależności od kraju UE [14].

Realizację populacyjnych badań przesiewowych mogą hamować różne przeszkody związane z systemem opieki zdrowotnej oraz te związane $z$ ustalaniem priorytetów politycznych. W „nowych" państwach członkowskich (które przystąpiły do UE po 2003 roku) poważnym problemem jest brak środków. Zapewnienie ciągłości finansowania jest warunkiem sukcesu programu, jak wynika z niedawnych doświadczeń Polski [15].

W "starych" państwach członkowskich organizacja badań przesiewowych może być sprzeczna z funkcjonującym systemem płatności za usługi medyczne. W 1996 roku Holandia zatrzymała refinansowanie rozmazów realizowanych poza programem, aby zmniejszyć ich liczbę [16]. W Anglii w 1990 roku wprowadzono wynagrodzenie "uzależnione od wyników" dla lekarzy ogólnych, aby zachęcić ich do włączenia swoich pacjentek do programu badań przesiewowych. Nie było żadnej wypłaty, jeśli uczestnictwo pacjentek w badaniach było poniżej 50\%, małe wypłaty, jeśli wynosiło od $50 \%$ do $79 \%$, i wyższe, gdy osiągnęło $80 \%$ [17].

Kilka krajów napotkało problem związany z poufnością danych, mimo że dyrektywa UE w sprawie ochrony danych [18] pozwala na ich powiązywanie m.in. dla celów medycyny prewencyjnej. Do monitorowania jakości i skuteczności realizowanych programów mogą być stosowane wskaźniki podane w wytycznych europejskich, jednak jest oczywiste, że te wskaźniki mogą być obliczane tylko wtedy, jeśli jest dostęp do niezbędnych danych. Na przykład, obliczenie współczynnika raka interwałowego jako proporcji oczekiwanego współczynnika zachorowalności na raka piersi w sytuacji braku skriningu [2] wymaga dostępu do danych dotyczących wszystkich kobiet, z mammografami zgodnymi z kryteriami jakości oraz do danych indywidualnych follow-up każdej kobiety, u której wystąpił rak, śmierć lub emigracja. Ponadto muszą być dostępne dane populacyjne dotyczące częstości występowania raka piersi przed rozpoczęciem badań przesiewowych. Zachęcające jest to, że wskaźnik ten został obliczony dla kilku europejskich programów przesiewowych w kierunku raka piersi [19].

Ewaluacja może również wymagać łączenia danych, które zostały oddzielone w przeszłości. W Szwecji odpo- 
wiedzialność za raka szyjki macicy spoczywa na gminach, które również prowadzą odpowiednie rejestry. W celu przeprowadzenia krajowego audytu programu przesiewowego pobierano i połączono dane z 30 laboratoriów patologicznych oraz cytologicznych z całej Szwecji. Używane lokalnie oznaczenia przekształcono na wspólny kod [20]. Jeśli działają krajowe bazy danych o ujednoliconym kodowaniu, możliwa jest identyfikacja regionalnych różnic w efektach zdrowotnych po wprowadzeniu skriningu; rutynowa praktyka w programach w Anglii [21] i Włoszech [22]. Centralizacja działań ułatwia także ich monitorowanie. Obowiązek nałożony przez UE, by ogłaszać przetargi na świadczenie usług na dużą skalę, niekiedy utrudnia centralizację, tak jak w przypadku usług cytologicznych.

Odniesienie się do istniejącej struktury administracyjno-własnościowej oraz odpowiednie dostosowanie jej do lokalnego systemu ochrony zdrowia są ważnymi czynnikami sukcesu. We Francji niezorganizowane, indywidualne badania mammograficzne były normą do 2004 roku, kiedy to mammografia stała się elementem programu narodowego. Zorganizowany program badań przesiewowych przejmuje więc pewne istniejące już praktyki, na przykład, badanie przesiewowe obejmuje badanie kliniczne, tj. uzyskanie obrazu z co najmniej dwóch projekcji piersi. Jeśli są nadal niejasności, to wykonuje się kolejny obraz; wszystkie zdjęcia wykonane są przez akredytowanych radiologów [23]. W Anglii zorganizowany program skriningowy rozpoczął się znacznie wcześniej, bo w 1988 roku. Radiolog ze specjalnym przeszkoleniem mammograficznym wykonywał dwa obrazy każdej piersi, a cała wizyta trwała około pół godziny [24].

Porównanie wskaźników efektywności z różnych krajów służy jako narzędzie do monitorowania możliwych skutków dostosowania programów badań przesiewowych do lokalnych systemów opieki zdrowotnej. Na przykład wyniki wybranych europejskich programów badań przesiewowych w kierunku raka piersi wykazały, że wskaźnik wykrywalności raka podzielony przez podstawowy wskaźnik zachorowalności był nieco wyższy w Kopenhadze (3.2), gdzie program przypominał funkcjonowanie programu w Anglii, niż w Marsylii (2.5) oraz w Strasburgu (2.9) [25].

Aby zapewnić trwałość programu badań przesiewowych, nowe dowody dotyczące metod kontroli skriningu powinny być regularnie przeglądane, natomiast potencjalne implikacje dla polityki programowej powinny być uznawane np. w odniesieniu do nowych technologii, takich jak np. sigmoidoskopia [26], lubłączenia badań przesiewowych z innymi metodami profilatycznymi, jak np. szczepionka przeciwko wirusowi brodawczaka ludzkiego (HPV) [27]. Wytyczne oparte na dowodach naukowych powinny być regularnie aktualizowane.
Powszechne rozumienie społecznych korzyści i zagrożeń wynikających z badań przesiewowych jest również niezbędne dla stabilności działania skutecznego programu badań przesiewowych. Wiele europejskich wskaźników ma na celu wczesne wskazanie korzyści i zagrożeń związanych z badaniami przesiewowymi, jednak potrzebna jest długoterminowa obserwacja, aby dokładnie ocenić zarówno korzyści w zmniejszaniu umieralności z powodu konkretnego raka, jak i ryzyko naddiagnozy. Wyzwania metodologiczne, wiążące się z długofalowymi badaniami z użyciem obserwacyjnych danych [28], sprawiają, że szczególnie ważne staje się to, aby zapewnić trwały dostęp i możliwość zarządzania poszczególnymi danymi.

Biorąc pod uwagę dużą liczbę osób biorących udział w programach badań przesiewowych, jest sprawą najwyższej wagi, aby uniknąć ryzyka związanego z ich niską jakością. Aby budować zaufanie społeczne, powinno być możliwe zidentyfikowanie i wykluczenie sytuacji, w których jakość nie jest na odpowiednim poziomie. Jest to trudne, ponieważ pomyłki się zdarzają. Dobrym przykładem są działania podejmowane w Anglii w następstwie stwierdzonych uchybień w przeprowadzaniu skriningu w kierunku raka szyjki macicy [29]. Jeśli zasoby są ograniczone, to lepiej podjąć się realizacji programu badań przesiewowych w kierunku tylko jednego nowotworu, niż rozpoczynać program skriningowy w kierunku trzech lokalizacji nowotworów równocześnie. Ustalanie priorytetów może być dokonane między innymi na podstawie liczby przypadków, woli politycznej oraz dostępności fachowej wiedzy i gotowości do udziału w programie. Szczegółowe wykazy umieszczone w niniejszej pracy mogą służyć jako przewodnik do stopniowego i skutecznego wdrożenia programu skriningowego.

\section{Wnioski}

Programy przesiewowe muszą być skutecznie realizowane i obsługiwane zgodnie z wartościami i priorytetami społecznymi. Warunki wstępne, jakie stawia się skutecznemu programowi badań przesiewowych, to: akceptacja społeczna, lokalne „poczucie własności” i skuteczna koordynacja oraz najlepsze praktyki oparte na dowodach.

Ze względu na złożoność procesu wdrażania nie jest zaskakujące to, że 10 lub więcej lat musi upłynąć, aby funkcjonowanie skriningów się ustabilizowało. W celu realizacji skriningu wymagana jest skuteczna i trwała koordynacja od początku procesu, jasna wizja każdego etapu, odpowiednie środki, przywództwo, konsensus zainteresowanych stron oraz umiejętność dostosowania się do zmieniających się potrzeb programu. 


\section{Konflikt interesu:}

Autorzy artykułu zadeklarowali potencjalne konflikty interesów i złożyli podziękowania następującym osobom: Susanne V Allander, Ahti Anttila, Magdalena Bielska-Lasota, Dorine Coenen, Thomas Davidson, Euzebiusz Dziwiński, Karl Freese, Louise Gunning, Monica Hultcrantz, Gunta Lazdane, Sue Moss, Måns Rosén, Leo van Rossum, Chris de Wolf, Maja Primic Žakelj, Jose Manuel Baena, Luc Bleyen, Mirelle Broeders, Luis Bujanda, José Expósito, Roger Pla Farnós, Xandra Gravenstein, Rosella Hermans, Roland Holland, Harry de Koning, Chris Meijer, Nieves Ascunce Elizaga, Xavier Castells Oliveres, Julietta Patnick, Marina Pollán, Dolores Salas, Hélène Sancho-Garnier i Jaroslav Volf.

Autorzy tłumaczenia nie zgłaszają konfliktu interesów.

\section{Mgr Anna Dębska}

Narodowy Instytut Zdrowia Publicznego

- Państwowy Zakład Higieny

ul. Chocimska 24, 00-791 Warszawa

e-mail:adebska@pzh.gov.pl

\section{Piśmiennictwo}

1. Zalecenie Rady UE z dnia 2 grudnia 2003 r. w sprawie badań przesiewowych w kierunku raka (2003/878/WE): Dz.U. L 327/34-38.

2. Perry N, Broeders M. De Wolf C i wsp. European guidelines for quality assurance in breast cancer screening and diagnosis. Fourth edition. Luxembourg: Office for official publications of the European Communities; 2006.

3. Arbyn M, Anttila A, Jordan Ji wsp. European guidelines for quality assurance in cervical cancer screening. Second edition. Luxembourg: Office for official publications of the European Communities; 2008.

4. Segnan N, Patnick J, von Karsa L. European guidelines for quality assurance in colorectal cancer screening and diagnosis. Luxembourg: Publication office of the European Union; 2010.

5. The UK CRC Screening Pilot Evaluation Team. Evaluation of the UK colorectal cancer screening pilot. Raport końcowy; 2003. http://www.cancerscreening.nhs.uk/bowel/ pilot-evaluation.html [Dostęp 3 marca 2011].

6. Chiu SY, Malila N, Yen AM i wsp. Analytical decision model for sample size and effectiveness projections for use in planning a population-based randomized controlled trial of colorectal cancer screening. J Eval Clin Pract 2011;17: 123-129.

7. Hakama M, Pukkala E, Soderman B, Day N. Implementation of screening as a public health policy: issues in design and evaluation. J Med Screen 1999; 6: 209-216.

8. Sweet D, Vanvossel A (red.). Europe against cancer. Public health: initiatives and texts adopted in 1990. Luxembourg: Office for Official Publications of the European Communities; 1990.

9. Kirkpatrick A, Törnberg S, Thijssen MAO. European guidelines for quality assurance in mammography screening. Luxembourg: Office for Official Publications of the European Communities; 1993.
10. Coleman D, Day N, Douglas G i wsp. European guidelines for quality assurance in cervical cancer screening. Eur J Cancer 1993; 29A Suppl 4: S1-38.

11. Recommendations on cancer screening in the European Union. Advisory Committee on Cancer Prevention. Eur J Cancer 2000; 36: 1473-1478.

12. von Karsa L, Anttila A, Ronco G i wsp. Cancer screening in the European Union. Luxembourg: European Communities, 2008.

13. Zorzi M, Baracco S, Fedato C i wsp. Screening for colorectal cancer in Italy: 2008 survey. Epidemiol Prev 2010;34 (5-6 Suppl 4):53-72.

14. Anttila A. von Karsa L, Aasmaa A i wsp. Cervical cancer screening policies and coverage in Europe. Eur J Cancer 2009; 45: 2649-2658.

15. Spaczyński M, Karowicz-Bilinska A, Kedzia W i wsp. Costs of population cervical cancer screening program in Poland between 2007-2009. Ginekol Pol 2010;81:750-6 [in Polish].

16. Rebolj $M$, van Ballegoijen $M$, Berkers LM i wsp. Monitoring a national cancer prevention program: successful changes in cervical cancer screening in the Netherlands. Int J Cancer 2007; 120: 806-812.

17. Patnick J. Cervical cancer screening in England. Eur J Cancer 2000; 36: 2205-2208.

18. Dyrektywa 95/46/WE Parlamentu Europejskiego i Rady z dnia 24 października 1995 r. w sprawie ochrony osób fizycznych w zakresie przetwarzania danych osobowych i swobodnego przepływu tych danych. Dz.U. L 281 z 23.11.1995, str. 31

19. Törnberg S, Kemetli L, Ascunce $\mathrm{N}$ i wsp. A pooled analysis of interval cancer rates in six European countries. Eur J Cancer Prev 2010; 19: 87-93.

20. Andrae B, Kemetli L, Sparén P i wsp. Screening-preventable cervical cancer risks: evidence from a nationwide audit in Sweden. $J$ Nat/ Cancer Inst 2008; 100: 622-629.

21. National Statistics. Breast screening programme 2008-09. http:// www.ic.nhs.uk/statistics-and-data-collections/screening/breast-screening/breast-screening-programme-england-2008-09 [Dostęp 8 czerwca 2011].

22. Zappa M, Grazzini G, Naldoni C i wsp. Introduction. The diffusion of screening programmes in Italy: 2008. Epidemiol Prev 2010; 34 (5-6 Suppl 4): 5-8.

23. Séradour B, Ancelle-Park R. Breast cancer screening: are results of French and international programmes comparable? J Radiol 2006; 87: 1009-1014 [Fr].

24. NHS Breast screening programme. Breast screening a pocket guide http://www.cancerscreening.nhs.uk/breastscreen/ publications/a-pocket-guide.html [Dostęp 7 czerwca 2011].

25. Broeders MJ, Scharpantgen A, Ascunce N i wsp. Comparison of early performance indicators for screening projects within the European Breast Cancer Network: 1989-2000. Eur J Cancer Prev 2005; 14: 107-116.

26. Atkin WS, Edwards R, Kralj-Hans I i wsp. Once-only flexible sigmoidoscopy screening in prevention of colorectal cancer: a multicentre randomized controlled trial. Lancet 2010; 375: 1624-1633.

27. Lynge E, Antilla A, Arbyn M i wsp. What's next? Perspectives and future needs of cervical screening in Europe in the era of molecular testing and vaccination. Eur J Cancer 2009; 45: 2714-2721.

28. Duffy SW, Lynge $\mathrm{E}$, Jonsson $\mathrm{H}$ i wsp. Complexities in the estimation of overdiagnosis in breast cancer screening. Br J Cancer 2008; 99: 1176-1178.

29. Cervical Screening Action Team: The report. NHS Executive: 1998. http:// www.dh.gov.uk/en/Publicationsandstatistics/Publications/PublicationsPolicyAndGuidance/DH_4005789 [Dostęp 7 czerwca 2011]. 